\title{
Occurrence of true spiders associated with some fruit trees at Sohag governorate, Egypt
}

\author{
Rashwan A. M. A. ${ }^{\mathrm{a}}$, Ahmed M. A. ${ }^{\mathrm{a}}$, Mohafez M. A. M. ${ }^{\mathrm{b}}$, Ahmed H. S. K. ${ }^{\mathrm{a}^{*}}$ \\ ${ }^{a}$ Agricultural Zoology and Nematology Department, Faculty of Agriculture, Al-Azhar University, Assiut, Egypt \\ ${ }^{b}$ Agricultural Zoology and Nematology Department, Faculty of Agriculture, Al-Azhar University, Cairo, Egypt
}

\begin{abstract}
This study was carried out to determine the frequency of occurrence and the presence of true spider associated with banana, citrus, grape and guava fruit trees. This study was conducted at El-Menshah and Tahta districts at sohag governorate, Egypt during two successive years 2018/2019 and 2019/2020. A total of specimens belonging to 75 species, 48 genera and 32 families were collected. The most dominant family with the largest number of species were Lycosidae, Philodromidae, Theridiidae, Cheiracanthiidae, Salticidae, Gnaphosidae and Thomisidae. While, the families Titanoecidae, Dictynidae, Scytodidae, Hersiliidae, Sparassidae, Corinnidae, Oonopidae, Eresidae, Liocranidae, Pisauridae, Agelenidae and Tetragnathidae including few species. As spiders are potential biological control agents of fruit orchard's pests, so any practice that may disrupt this group should be avoided by the farmers.
\end{abstract}

Keywords: true spiders, fruit trees, Sohag, Egypt. 


\section{Introduction}

Spiders are one of the more diverse arthropod taxa, ranking in global diversity, which makes them a fascinating group to study (Coddington and Levi, 1991). True spiders are worldwide distributed and occupy many ecological environments through agroecosystems. True spiders are one of the most abundance predatory groups in terrestrial ecosystems spiders have proved to be beneficial in regulation of agricultural pests and their role as natural enemies has recently been more and more stressed (Ghabbor et al., 1999). All spiders are considered as biocontrol agents, they attack most of pests infesting crops, vegetables, ornamental and orchard fruit trees (Ghavani, 2006; Luczak, 1979). On the other hand, spiders feed and consume phytophagous mites also, they can feed and consume usefully lepidopteran insect larvae. Ecological parameters and taxonomic importance of different species of spiders from some, fruit orchards (i.e., apple, citrus, grape, guava, fig, and mango fruit gardens were investigated by many researchers (Abo-Zaed Amal and Mansour, 2019; Metwally, 2012; Mohafez, 2000; Sallam, 1996). The aim of this work is to study the occurrence and distribution of the most common families and species of spiders associated with four fruit trees orchards (banana, citrus, grape, guava trees). In two districts El-Menshah and Tahta at Sohag governorate, Egypt during two successive years (2018/2019 and 2019/2020).

\section{Materials and methods}

This study was conducted in old areas at two districts (El-Menshah and Tahta) at sohag governorate, Egypt during two successive years $(2018 / 2019$ and 2019/2020), respectively. Individuals of the true spiders were randomly collected from four fruit orchards banana (Musa sp.), citrus (Citrus medica), grape (Vitis vinifera) and guava (Psidium guajava). In the fields by tree methods as follow: (1) Pitfall traps: The pitfall traps consist of plastic bowls $(6 \mathrm{~cm}$ diameter and $8 \mathrm{~cm}$ depth). Into which $6 \mathrm{~m} 1$ of foamy soup solution was added. Traps were set at different sampling sits on 5 meters distance of each other (Southwood, 1987). (2) Branch shaking: For citrus trees, 6-8 branches were chosen randomly and shacked for each sample. For branches were 100-125 cm. large number of leaves was shacked over the shaking cloth. After shacking specimens were individually picked up in a plastic vial $(2 \times 5 \mathrm{~cm})$; while larger ones kept in vial $(2 \times 5 \mathrm{~cm})$; and transferred to the laboratory for counting and identification. Individual adult males and females were isolated for ecological studies. The collected spiders were preserved in 70\% alcohol and transferred to laboratory for classification. Locality, habitat, date of collected samples and other information were recorded attached to each specimen in the side of tube. 
(3) Hand sorting: Spiders were picked handily, the big individuals kept in tubes and small ones collected by gimel's hairbrush and kept into the plastic tubes $(1 \times 4 \mathrm{~cm})$. Samples were collected monthly for one hour from 11-12 am in the winter and 10-11 am in the summer.

\subsection{Classification studies}

All specimens after transfer to laboratory, examined and kept in petri dish of $10 \mathrm{~cm}$ diameter, the individual examined using a stereoscopic binocular microscope. Each specimen was individually kept in a large tube containing 70\% alcohol; date of collection, locality, host plant and other information were recorded in the side of each tube. Samples of spiders were identified according to nomenclatures of Petrunkvitch (1939) and Kaston (1978).

\subsection{Statistical analysis}

Population density and frequency of occurrence of spider families and species were determined according to their localities and sort of fruit trees using to the following equations: all obtained data were statistically analyzed according to Duncan (1955).

Population density $(P . D)=.\frac{\text { Total number of family or species individuals }}{\text { Number of samples containing this family or species }}$

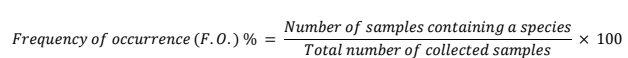

\section{Results and Discussion}

Data presented in Table (1) showed the seventy-five spider species, forty-eight genera and thirty-two families. All collected spiders belonging to Suborder Araneomorphae (Labidognatha), this group are usually referred to as true spiders. These families were Agelenidae, Araneidae, Cheiracanthiidae, Clubionidae, Corinnidae, Dictynidae, Dysderidae, Eresidae, Filistatidae, Gnaphosidae, Hersiliidae, Linyphiidae, Liocranidae, Lycosidae, Mimetidae, Oecobiidae, Oonopidae, Oxyopidae, Philodromidae, Pholcidae, Pisauridae, Prodidomidae, Salticidae, Scytodidae, Sparassidae, Sicariidae, Tetragnathidae, Theridiidae, Thomisidae, Titanoecidae, Trachelidae and Uloboridae. These spiders varied greatly in their population densities and frequencies of occurrence according to the type of locality. However, the families Lycosidae, Philodromidae, Theridiidae, Cheiracanthiidae, Salticidae, Gnaphosidae and Thomisidae were found with relatively highly population densities and frequencies of occurrence during the two years (2018/2019 and 2019/2020), respectively. 
Table (1): Population density and frequency of occurrence of spider families and species associated with fruit Orchard in tow locations in Sohag governorate, Egypt.

\begin{tabular}{|c|c|c|c|c|c|c|c|c|}
\hline \multirow[b]{2}{*}{ Spider families \& species } & \multicolumn{4}{|c|}{ Districts } & \multirow{2}{*}{$\begin{array}{l}\text { Total individuals of } \\
\text { families or species }\end{array}$} & \multirow{2}{*}{$\begin{array}{c}\text { Total No. of } \\
\text { samples containing } \\
\text { families or Species }\end{array}$} & \multirow[b]{2}{*}{$\mathrm{PD}$} & \multirow[b]{2}{*}{$\mathrm{FO}(\%)$} \\
\hline & \multicolumn{2}{|c|}{ Al-Minshah } & \multicolumn{2}{|c|}{ Tahta } & & & & \\
\hline Agelenidae (Koch, 1837) & 1.50 & 8.33 & 2.00 & 4.17 & 7 & 3 & 2.33 & 6.25 \\
\hline \begin{tabular}{l|l} 
Argiope sp. \\
\end{tabular} & 2.00 & 4.17 & 3.00 & 4.17 & 5 & 2 & 2.50 & 4.17 \\
\hline Cyrtophora citricola & 1.43 & 29.17 & 1.50 & 25.00 & 19 & 13 & 1.46 & 27.08 \\
\hline Unidentified species & 1.00 & 16.67 & 1.00 & 16.67 & 8 & 8 & 1.00 & 16.67 \\
\hline \begin{tabular}{|l} 
Cheiracanthium isiacum \\
\end{tabular} & 1.33 & 25.00 & 1.33 & 37.50 & 20 & 15 & 1.33 & 31.25 \\
\hline Cheiracanthium siwi & 2.00 & 16.67 & 1.00 & 12.50 & 11 & 7 & 1.57 & 14.58 \\
\hline Cheiracanthium sp. & 1.00 & 12.50 & 1.00 & 4.17 & 4 & 4 & 1.00 & 8.33 \\
\hline Clubionidae (Wagner, 1887) & 0.00 & 0.00 & 4.00 & 8.33 & 8 & 2 & 4.00 & 4.17 \\
\hline Corinnidae (Karsch, 1880) & 1.75 & 16.67 & 1.60 & 20.83 & 16 & 9 & 1.78 & 18.75 \\
\hline \begin{tabular}{l|l} 
Castianeira sp. \\
\end{tabular} & 1.00 & 4.17 & 0.00 & 0.00 & 1 & 1 & 1.00 & 2.08 \\
\hline Eresidae (Koch, 1845) & 1.75 & 16.67 & 1.33 & 12.50 & 11 & 7 & 1.57 & 14.58 \\
\hline Filistatidae (Ausserer, 1867) & 1.63 & 79.17 & 2.57 & 58.33 & 66 & 33 & 2.00 & 68.75 \\
\hline \begin{tabular}{l|l} 
Filistata insidiatrix \\
\end{tabular} & 1.00 & 12.50 & 1.00 & 12.50 & 6 & 6 & 1.00 & 12.50 \\
\hline Gnaphosidae (Pocock, 1898) & 5.45 & 91.67 & 6.39 & 95.83 & 317 & 45 & 7.04 & 93.75 \\
\hline \begin{tabular}{|l} 
Drassodes alexandrinus \\
\end{tabular} & 1.00 & 8.33 & 1.00 & 4.17 & 3 & 3 & 1.00 & 6.25 \\
\hline Drassyllus depressus & 1.00 & 4.17 & 0.00 & 0.00 & 1 & 1 & 1.00 & 2.08 \\
\hline Micaria dives & 1.50 & 8.33 & 2.13 & 33.33 & 20 & 10 & 2.00 & 20.83 \\
\hline Micaria sp. & 1.00 & 4.17 & 1.00 & 4.17 & 2 & 2 & 1.00 & 4.17 \\
\hline Poecilochroa pugnax & 1.00 & 4.17 & 0.00 & 0.00 & 1 & 1 & 1.00 & 2.08 \\
\hline Setaphis subtilis & 1.00 & 16.67 & 1.33 & 12.50 & 8 & 7 & 1.14 & 14.58 \\
\hline Erigone sp. & 1.00 & 4.17 & 1.00 & 8.33 & 3 & 3 & 1.00 & 6.25 \\
\hline Gnathonarium sp. & 1.00 & 8.33 & 0.00 & 0.00 & 2 & 2 & 1.00 & 4.17 \\
\hline Mermessus denticulatus & 1.00 & 8.33 & 1.00 & 8.33 & 4 & 4 & 1.00 & 8.33 \\
\hline Prinerigone vagans & 1.00 & 4.17 & 0.00 & 0.00 & 1 & 1 & 1.00 & 2.08 \\
\hline Sengletus extricatus & 1.50 & 16.67 & 1.00 & 8.33 & 8 & 6 & 1.33 & 12.50 \\
\hline Sengletus sp. & 1.00 & 8.33 & 1.00 & 4.17 & 3 & 3 & 1.00 & 6.25 \\
\hline Unidentified species & 1.00 & 4.17 & 0.00 & 0.00 & 1 & 1 & 1.00 & 2.08 \\
\hline Liocranidae (Simon, 1897) & 1.00 & 12.50 & 1.67 & 12.50 & 11 & 6 & 5.33 & 12.50 \\
\hline Lycosidae (Sundevall, 1833) & 9.50 & 100.00 & 9.14 & 91.67 & 476 & 46 & 10.35 & 95.83 \\
\hline Hogna ferox & 2.00 & 4.17 & 1.50 & 8.33 & 5 & 3 & 1.67 & 6.25 \\
\hline Hogna sp. & 2.00 & 4.17 & 1.00 & 12.50 & 5 & 4 & 1.25 & 8.33 \\
\hline lycosa $\mathrm{sp}$. & 0.00 & 0.00 & 1.67 & 12.50 & 5 & 3 & 1.67 & 6.25 \\
\hline Pardosa inquieta & 1.00 & 4.17 & 1.00 & 4.17 & 2 & 2 & 1.00 & 4.17 \\
\hline Pardosa sp. & 1.60 & 20.83 & 1.25 & 33.33 & 18 & 13 & 1.38 & 27.08 \\
\hline Trochosa urbana & 2.33 & 25.00 & 1.14 & 29.17 & 22 & 13 & 1.69 & 27.08 \\
\hline Trochosa sp. & 1.00 & 4.17 & 00.00 & 0.00 & 1 & 1 & 1.00 & 2.08 \\
\hline Wadicosa fidelis & 1.60 & 20.83 & 2.00 & 12.50 & 14 & 8 & 1.75 & 16.67 \\
\hline \begin{tabular}{l|} 
Unidentified species \\
\end{tabular} & 1.00 & 8.33 & 1.00 & 4.17 & 3 & 3 & 1.00 & 6.25 \\
\hline Mimetidae (Simon, 1881) & 4.00 & 4.17 & 0.00 & 0.00 & 4 & 1 & 4.00 & 2.08 \\
\hline Oecobiidae (Blackwall, 1862) & 2.56 & 37.50 & 1.75 & 50.00 & 56 & 21 & 2.67 & 43.75 \\
\hline \begin{tabular}{l|l} 
Oecobius navus \\
\end{tabular} & 2.00 & 4.17 & 2.00 & 4.17 & 4 & 2 & 2.00 & 4.17 \\
\hline Oecobius putus & 1.00 & 4.17 & 3.00 & 4.17 & 4 & 2 & 2.00 & 4.17 \\
\hline
\end{tabular}


Rashwan et al. / Archives of Agriculture Sciences Journal 4(2) 320-328, 2021.

Table (1): Continued

\begin{tabular}{|c|c|c|c|c|c|c|c|c|}
\hline \multirow{3}{*}{ Spider families \& species } & \multicolumn{4}{|c|}{ Districts } & \multirow{3}{*}{$\begin{array}{l}\text { Total individuals of } \\
\text { families or species }\end{array}$} & \multirow{3}{*}{$\begin{array}{c}\text { Total No. of } \\
\text { samples containing } \\
\text { families or Species }\end{array}$} & \multirow{3}{*}{ PD } & \multirow{3}{*}{$\mathrm{FO}(\%)$} \\
\hline & \multicolumn{2}{|c|}{ Al-Minshah } & \multicolumn{2}{|c|}{ Tahta } & & & & \\
\hline & PD & FO & PD & FO & & & & \\
\hline Philodromidae (Thorell, 1870) & 7.33 & 100.00 & 6.04 & 100.00 & 472 & 48 & 9.83 & 100.00 \\
\hline Philodromus sp. & 1.29 & 29.17 & 1.33 & 37.50 & 21 & 16 & 1.31 & 33.33 \\
\hline Thanatus albini & 2.25 & 33.33 & 2.25 & 66.67 & 54 & 24 & 2.25 & 50.00 \\
\hline Pholcidae (Koch, 1850) & 1.93 & 58.33 & 2.12 & 70.83 & 124 & 31 & 4.00 & 64.58 \\
\hline Artema sp. & 2.00 & 4.17 & 2.50 & 8.33 & 7 & 3 & 2.33 & 6.25 \\
\hline Micropholcus fauroti & 2.00 & 8.33 & 1.67 & 12.50 & 9 & 5 & 1.80 & 10.42 \\
\hline Micropholcus sp. & 1.33 & 12.50 & 1.33 & 12.50 & 8 & 6 & 1.33 & 12.50 \\
\hline Pholcus sp. & 1.00 & 8.33 & 1.00 & 8.33 & 4 & 4 & 1.00 & 8.33 \\
\hline Pisauridae (Simon, 1890) & 1.20 & 20.83 & 1.00 & 8.33 & 8 & 7 & 1.14 & 14.58 \\
\hline Unidentified species & 1.00 & 8.33 & 1.00 & 4.17 & 3 & 3 & 1.00 & 6.25 \\
\hline Prodidomidae (Simon, 1884) & 0.00 & 0.00 & 6.50 & 8.33 & 13 & 2 & 6.50 & 4.17 \\
\hline Salticidae (Blackwall, 1841) & 7.10 & 83.33 & 7.92 & 100.00 & 373 & 44 & 8.48 & 91.67 \\
\hline Bianor albobimaculatus & 1.00 & 4.17 & 0.00 & 0.00 & 1 & 1 & 1.00 & 2.08 \\
\hline Hasarius sp. & 0.00 & 0.00 & 1.00 & 4.17 & 1 & 1 & 1.00 & 2.08 \\
\hline Heliophanus edentulus & 1.00 & 4.17 & 0.00 & 0.00 & 1 & 1 & 1.00 & 2.08 \\
\hline Heliophanus sp. & 2.00 & 12.50 & 2.00 & 12.50 & 12 & 6 & 2.00 & 12.50 \\
\hline Plexippus paykulli & 1.50 & 16.67 & 1.57 & 29.17 & 17 & 11 & 1.55 & 22.92 \\
\hline Plexippus sp. & 1.00 & 4.17 & 1.50 & 8.33 & 4 & 3 & 1.33 & 6.25 \\
\hline Pseudicius spiniger & 2.00 & 4.17 & 2.00 & 12.50 & 8 & 4 & 2.00 & 8.33 \\
\hline Synageles dalmaticus & 3.00 & 4.17 & 1.50 & 8.33 & 6 & 3 & 2.00 & 6.25 \\
\hline Synageles $\mathrm{sp}$. & 1.00 & 4.17 & 0.00 & 0.00 & 1 & 1 & 1.00 & 2.08 \\
\hline Thyene imperialis & 2.00 & 8.33 & 1.80 & 41.67 & 22 & 12 & 1.83 & 25.00 \\
\hline Unidentified species & 1.50 & 16.67 & 1.00 & 8.33 & 8 & 6 & 1.33 & 12.50 \\
\hline Scytodidae (Blackwall, 1864) & 1.45 & 45.83 & 3.71 & 29.17 & 33 & 18 & 1.83 & 37.50 \\
\hline Scytodes $\mathrm{sp}$ & 1.00 & 8.33 & 0.00 & 0.00 & 2 & 2 & 1.00 & 4.17 \\
\hline Sicariidae (Keyserling, 1880) & 0.00 & 0.00 & 6.00 & 4.17 & 6 & 1 & 6.00 & 2.08 \\
\hline Sparassidae (Bertkau, 1872) & 1.33 & 25.00 & 1.40 & 20.83 & 17 & 11 & 1.55 & 22.92 \\
\hline Eusparassus walckenaeri & 1.00 & 12.50 & 2.00 & 4.17 & 5 & 4 & 1.25 & 8.33 \\
\hline Tetragnathidae (Menge, 1866) & 2.00 & 4.17 & 1.67 & 12.50 & 7 & 4 & 1.75 & 8.33 \\
\hline Theridiidae (Sundevall, 1833) & 6.29 & 100.00 & 7.92 & 100.00 & 397 & 48 & 8.27 & 100.00 \\
\hline Kochiura aulica & 1.00 & 8.33 & 2.00 & 4.17 & 4 & 3 & 1.33 & 6.25 \\
\hline Steatoda erigoniformis & 1.50 & 33.33 & 1.00 & 12.50 & 15 & 11 & 1.36 & 22.92 \\
\hline Steatoda $\mathrm{sp}$. & 2.33 & 25.00 & 1.75 & 33.33 & 28 & 14 & 2.00 & 29.17 \\
\hline Steatoda triangulosa & 2.14 & 29.17 & 1.33 & 37.50 & 27 & 16 & 1.69 & 33.33 \\
\hline Theridion incanescens & 1.20 & 20.83 & 2.50 & 8.33 & 11 & 7 & 1.57 & 14.58 \\
\hline Theridion jordanense & 1.33 & 12.50 & 4.00 & 4.17 & 8 & 4 & 2.00 & 8.33 \\
\hline Theridion melanostictum & 1.20 & 20.83 & 1.20 & 20.83 & 12 & 10 & 1.20 & 20.83 \\
\hline Theridion $\mathrm{sp}$. & 1.40 & 20.83 & 1.78 & 37.50 & 23 & 14 & 1.64 & 29.17 \\
\hline Theridion spinitarse & 1.00 & 12.50 & 1.33 & 12.50 & 7 & 6 & 1.17 & 12.50 \\
\hline Theridion varians & 1.67 & 12.50 & 1.00 & 12.50 & 5 & 6 & 0.83 & 12.50 \\
\hline Unidentified species & 1.00 & 25.00 & 1.00 & 4.17 & 7 & 7 & 1.00 & 14.58 \\
\hline Thomisidae (Sundevall, 1833) & 2.36 & 91.67 & 3.61 & 75.00 & 186 & 40 & 4.65 & 83.33 \\
\hline Synema sp. & 1.00 & 8.33 & 3.00 & 4.17 & 5 & 3 & 1.67 & 6.25 \\
\hline Thomisus sp. & 0.00 & 0.00 & 1.00 & 4.17 & 1 & 1 & 1.00 & 2.08 \\
\hline Thomisus spinifer & 1.00 & 4.17 & 1.45 & 45.83 & 17 & 12 & 1.42 & 25.00 \\
\hline Xysticus sp. & 1.00 & 29.17 & 1.14 & 29.17 & 15 & 14 & 1.07 & 29.17 \\
\hline Unidentified species & 1.50 & 16.67 & 1.20 & 20.83 & 12 & 9 & 1.33 & 18.75 \\
\hline Titanoecidae (Lehtinen, 1967) & 1.50 & 16.67 & 1.20 & 20.83 & 40 & 9 & 4.44 & 18.75 \\
\hline Nurscia albomaculata & 0.00 & 0.00 & 1.50 & 33.33 & 3 & 2 & 1.50 & 4.17 \\
\hline Nurscia sp. & 1.25 & 16.67 & 2.00 & 16.67 & 3 & 2 & 1.50 & 4.17 \\
\hline Unidentified species & 2.00 & 50.00 & 2.00 & 33.33 & 6 & 3 & 2.00 & 6.25 \\
\hline Trachelidae (Simon, 1890) & 0.00 & 0.00 & 1.50 & 8.33 & 8 & 2 & 4.00 & 4.17 \\
\hline Uloboridae (Thorell, 1869) & 1.67 & 50.00 & 1.63 & 66.67 & 46 & 28 & 1.64 & 58.33 \\
\hline Uloborus .sp & 1.00 & 8.33 & 1.00 & 4.17 & 3 & 3 & 1.00 & 6.25 \\
\hline Uloborus walckenaerius & 1.25 & 16.67 & 1.33 & 25.00 & 8 & 2 & 4.00 & 4.17 \\
\hline Unidentified species & 1.50 & 8.33 & 1.00 & 8.33 & 69 & 28 & 2.46 & 58.33 \\
\hline
\end{tabular}

Total No. of collected samples $=48$

$\mathrm{PD}=$ Population densities

FO $\%=$ Frequency of occurrence 
3.1 Population density and frequency of occurrence of spider families and species associated with fruit Orchard in tow locations in Sohag governorate, Egypt

Data in Table (1) indicated that the members of families Lycosidae, Philodromidae, Theridiidae, Cheiracanthiidae, Salticidae, Gnaphosidae and Thomisidae were represented in most surveyed spiders in the two districts (ElMenshah and Tahta) with highly total individuals reached $(476,472,397,392$, 373,317 and 186 individuals), whereas population density and frequency of occurrence (10.35 and 95.83\%), (9.83 and $100 \%),(8.27$ and $100 \%),(8.52$ and $95.83 \%),(8.48$ and $91.67 \%)$, (7.04 and $93.75 \%)$ and (4.65 and $83.33 \%)$, respectively during years (2018/2019 and 2019/2020). The families Araneidae, Linyphiidae, Pholcidae, Uloboridae, Filistatidae, Dysderidae and Oecobiidae were found in three localities with moderately total individuals reached (171, 134, 124, 69, 66, 64 and 56 individuals) with population density and frequency of occurrence $(4.75$ and $75.00 \%)$, (3.72 and $75.00 \%)$, (4.00 and $64.58 \%)$, (2.46 and 58.33\%), (2.00 and $68.75 \%),(2.21$ and $60.42 \%)$ and $(2.67$ and $43.75 \%$ ), respectively. Whereas the other families of spiders were recorded in lowest population densities and frequencies of occurrence. The families of Titanoecidae, Dictynidae, Scytodidae, Hersiliidae, Sparassidae, Corinnidae, Oonopidae, Eresidae, Liocranidae, Pisauridae, Agelenidae and Tetragnath- idae. were found in all localities with lower total individuals reached $(40,36$, $33,32,17,16,16,11,8,8,7$ and 7) with averaged lower values of their P.D. and F.O. \% they averaged (4.44 and $18.75 \%)$, (2.25 and $33.33 \%),(1.83$ and $37.50 \%)$, (2.29 and 29.17\%), (1.55 and 22.92\%), (1.78 and $18.75 \%)$, (1.60 and $20.83 \%)$, (1.57 and $14.58 \%)$, (1.33 and $12.50 \%)$, (1.14 and $14.58 \%),(2.33$ and $6.55 \%)$ and (1.75 and $8.33 \%)$, respectively. On the other hand, individuals of family Mimetidae were recorded only in ElMenshah with population density and frequency of occurrence averaged (4.00 and $2.08 \%$ ). Also, individuals of families Clubionidae, Oxyopidae, Prodidomidae, Sicariidae and Trachelidae. were recorde$\mathrm{d}$ only in Tahta with population density and frequency of occurrence averaged (4.00 and $4.17 \%)$, (3.00 and 2.08\%), (2.60 and $10.42 \%),(6.00$ and $2.08 \%)$ and $(4.00$ and $4.17 \%)$, respectively. Population of spider families associated with different fruit orchard in ElMenshah districts, Sohag governorate during two successive years, 2018/2019 and 2019/2020 (Table 1). The members of families Thomisidae, Araneidae, Linyphiidae and Pholicidae were represented in most surveyed samples in El-Menshah locality with moderately total reached $(92,91,76$ and 64 individuals), respectively, while, the families Lycosidae, Philodromidae, Cheiracanthiidae, Theridiidae, Salticidae and Gnaphosidae were found with highly total individuals reached $(228,222,212$, 204, 173 and 170 individuals), 
respectively, whereas, the other families of spiders were recorded in lowest total numbers. The variation in population densities and frequency of occurrence of spider families and species in all collected samples could be related to different environmental condition, i.e. temperature, moisture and the abundance of the kind fruit in the two districts at Sohag governorate. This is in accordance with the previous data obtained by several investigators (Baert et al., 1997; El-Erksousy, 2000; Mohafez, 2004; Sallam, 1996).

\subsection{Population density and frequency of} occurrence the spider species in relation to the tow localities

Concerning of the distribution of the true spider species also they varied in their population densities and frequencies of occurrence according to the tow surveyed districts El-Menshah, Tahta at Sohag Governorate are presented in Table (1). Thanatus albini, Steatoda sp., Steatoda triangulosa, Theridion sp., Trochosa urbana and Thyene imperialis were found in almost surveyed localities with total individuals, highly total individuals reached $(54,28,27,23,22$ and 22 individuals), also the average population densities and frequencies of occurrence were average (2.25 and 50.00\%), (2.00 and 29.17\%), (1.69 and 33.33\%), (1.64 and $27.17 \%)$, (1.69 and 27.08) and (1.92 and $16.67 \%$ ) respectively. On the other hand, Philodromus sp., Cheiracanthium isiacum, Micaria dives, Cyrtophora citricola, Pardosa sp., Plexippus paykulli, Thomisus spinifer and Trachyzelotes jaxartensis were found in three surveyed localities with moderately population densities and frequencies of occurrence. Therefore, the calculated of total individuals reached $21,(20,20,19$, $18,17,17$ and 16 individuals), also the average population densities and frequencies of occurrence were (1.31 and $33.33 \%)$, (1.33 and 31.25\%), (2.00 and $20.83 \%)$, (1.46 and $27.08 \%),(1.38$ and $27.08 \%),(1.55$ and $22.92 \%),(1.42$ and $25.00 \%)$ and (1.23 and 27.08\%) respectively. Whereas the other spider species were recorded in lowest population densities and frequencies of occurrence. The distribution of spider species associated with some fruit orchard in tow location (El-Menshah, Tahta in Sohag governorate is presented in Table (1). In El-Menshah district, seven spider species were recorded. The species were Thanatus albini, Steatoda triangulosa, Trochosa urbana, Steatoda sp., Steatoda erigoniformis, Cyrtophora citricola and Philodromus sp. were recorded with highly numbers reached (18, 15, 14, 14, 12, 10 and 9 individuals), also average population densities and frequencies of occurrence were (2.25 and $33.33 \%),(1.50$ and $33.33 \%)$, (2.33 and $25.00 \%),(2.33$ and $25.00 \%),(1.50$ and $33.33 \%)$, (1.43 and $29.17 \%)$ and (1.29 and $29.17 \%$ ), respectively, while members of species Cheiracanthium isiacum, Cheiracanthium siwi, and Zelotes sp. were recorded in moderate numbers 8 individuals for each of them. 
Also, the average population density and frequency of occurrence were (1.33 and $25.00 \%)$, (2.00 and $16.67 \%)$ and (1.33 and $25.00 \%$ ), respectively, while the other spider species recorded in lowest individuals (Table 1). In Tahta district, five spider species were recorded. The species were Thanatus albini, Thyene imperialis, Micaria dives, Theridion sp. and Thomisus spinifer. were recorded with highly numbers reached $(36,18,17$, 16 and 16 individuals), Also the average population densities and frequencies of occurrence were (2.25 and 66.67\%), (1.80 and 41.67\%), (2.13 and 33.33\%), $(1.78$ and $37.50 \%)$ and (1.45 and $45.83 \%$ ) respectively, while members of species Steatoda sp., Cheiracanthium isiacum, Trachyzelotes jaxartensis, Philodromus sp., Steatoda triangulosa and Plexippus paykulli were recorded in moderate numbers 12 individuals for each of them. Also, average population density and frequency of occurrence were (1.33 and $37.50 \%)$ for each of them, while the other spider species recorded the lowest individuals (Table 1).

\section{References}

Abo-Zaed Amal, E. and Mansour, M. A. (2019), "Occurrence of true spiders associated with citrus, apple and grape fruit orchards at Alexandria governorate in Egypt", Menoufia Journal of Plant protection, Vol. 4, pp. 121-128.

Baert, L., Ransy, M. and Fassotte, C. (1997), "The spiders (Araneae) of apple and pear orchards", Bulletin et annales de la Société royale belge d'entomologie, Vol. 133, pp. 445556.

Coddington, J. A. and Levi, H. W. (1991), "Systematics and evolution of spiders (Araneae)", Annual Review of Ecology, Evolution, and Systematics, Vol. 22, pp. 565-592.

Duncan, D. B. (1955), "Multiple range and multiple F tests", Biometrics, Vol. 11, pp. 1-42.

El-Erksousy, M. H. M. (2000), Studies on some true spiders in Egypt. Ph. D. Thesis, Faculty of Agriculture, Al-Azhar University, Egypt, pp. 132.

Ghabbour, S. I., Hussein, A. M. and ElHennawy, H. K. (1999), "Spider populations associated with different crops in Menoufiya Governorate, Nile Delta, Egypt", Journal of Agricultural Research, Vol. 77 No. 3, pp. 1163-1179.

Ghavani, S. (2006), "Abundance of spiders (Arachnida: Araneae) in olive orchards in Northern part of Iran", Pakistan Journal of Biological Sciences, Vol. 9 No. 5, pp. 795-799.

Kaston, B. J. (1978), How to know the true spiders, third Ed., William C. Brown Co., Duduque, Iowa, USA, pp. 272.

Luczak, M. C. (1979), "The spatial distribution of beneficial arthropods in winter wheat", Annals of Applied 
Biology, Vol. 136, pp. 93-105.

Metwaly, A. M., Abd El-Kader, M. R., Montaser, S. A., Ahmed, M. A. and Qurany, H. S. (2012), "Relative abundance and distribution of the true spider families in Assuit Governorate", Journal of Plant Protection and Pathology, Vol. 3 No. 2, pp. 81-89.

Mohafez, M. A. M. (2000), Studies on true spiders in Sohag Governorate, M.Sc. Thesis, Faculty of Agriculture, Al-Azhar University, Egypt, pp. 155.

Mohafez, M. A. M. (2004), Ecological and biological studies on spiders in Egypt, Ph.D. Thesis, Faculty of Agriculture, Al-Azhar University, Egypt, pp. 178.
Petrunkevitch, A. I. (1939), Catalog of American true spiders, Connecticut academy of arts and sciences, New Haven, Connecticut, USA.

Sallam, G. M. E. (1996), Studies on true spiders in Giza Governorate, M.Sc. Thesis, Faculty of Agriculture, Cairo University, Cairo, Egypt, pp. 139.

Southwood, T. R. E. (1987), Ecological methods with particular reference to the study of insect population, Chapman and Hall, London, England, pp. 524. 